\title{
MYCTERIA AUSTRALIS,
}

\section{CHARACTER GENERICUS.}

Rostrum subascendens, acutum, mandibula superiore triquetra.

Frons calva.

Nares lineares.

Pedes tetradactyli.

Lath. ind. orn. p. 670.

CHARACTER SPECIFICUS, Ec.

MYCTERIA alba, capite colloque viridi-nigris, tectricibus, pennis scapularibus, caudaque nigris, rostro nigro, pedibus rubris.

MYCTERIA AUSTRALIS.

Lin. Trans. Vol. 5. p. 34.

Generis Mycteriæ species $A$ mericana seu communis, physicis jamdiu cognita, varias Americæ Australis partes, incolit. Species autem quam depinximus, quamque generat Australasia, distat insigniter ab avi Americana, quod caput et collum non denudentur, sed plumis vestiantur saturatim viridibus, qualibus fere collucere solet Anas Boschas mas; splendore insuper versicolori vel in cæruleum vel purpureum transeunte. Rostrum nigrat; et a basi 
mandibulæ inferioris dependet extensa aliquatenus in gulam cutis quædam nuda, seu sacculus membranaceus ruberrimus. Cætera avis nivei est candoris, alarum tectricibus omnibus exceptis nigerrimis, nigraque cauda. Crura pedesque ruberrima. Icones accuratissime delineatæ sunt apud Dominum White, coloniæ Britannicæ in Australasia chirurgum præcipuum, unde constat hanc speciem, cum plene adoleveret, Mycteriæ ipsi Americanæ magnitudine esse parem; sex enim vel septem pedes alta depingitur. Speeimen autem nostrum quod ostendit tabula, quodque in Museo Leveriano asservatur, vix quinque pedes superat. 


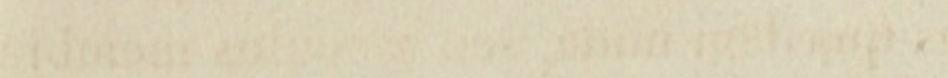

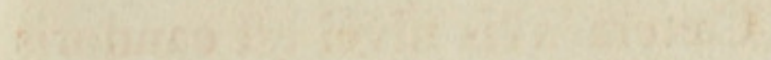

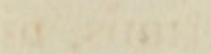

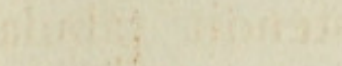

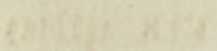




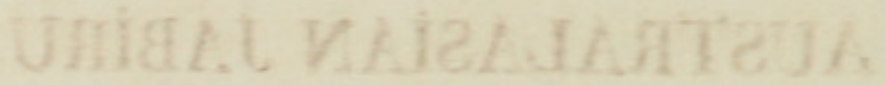

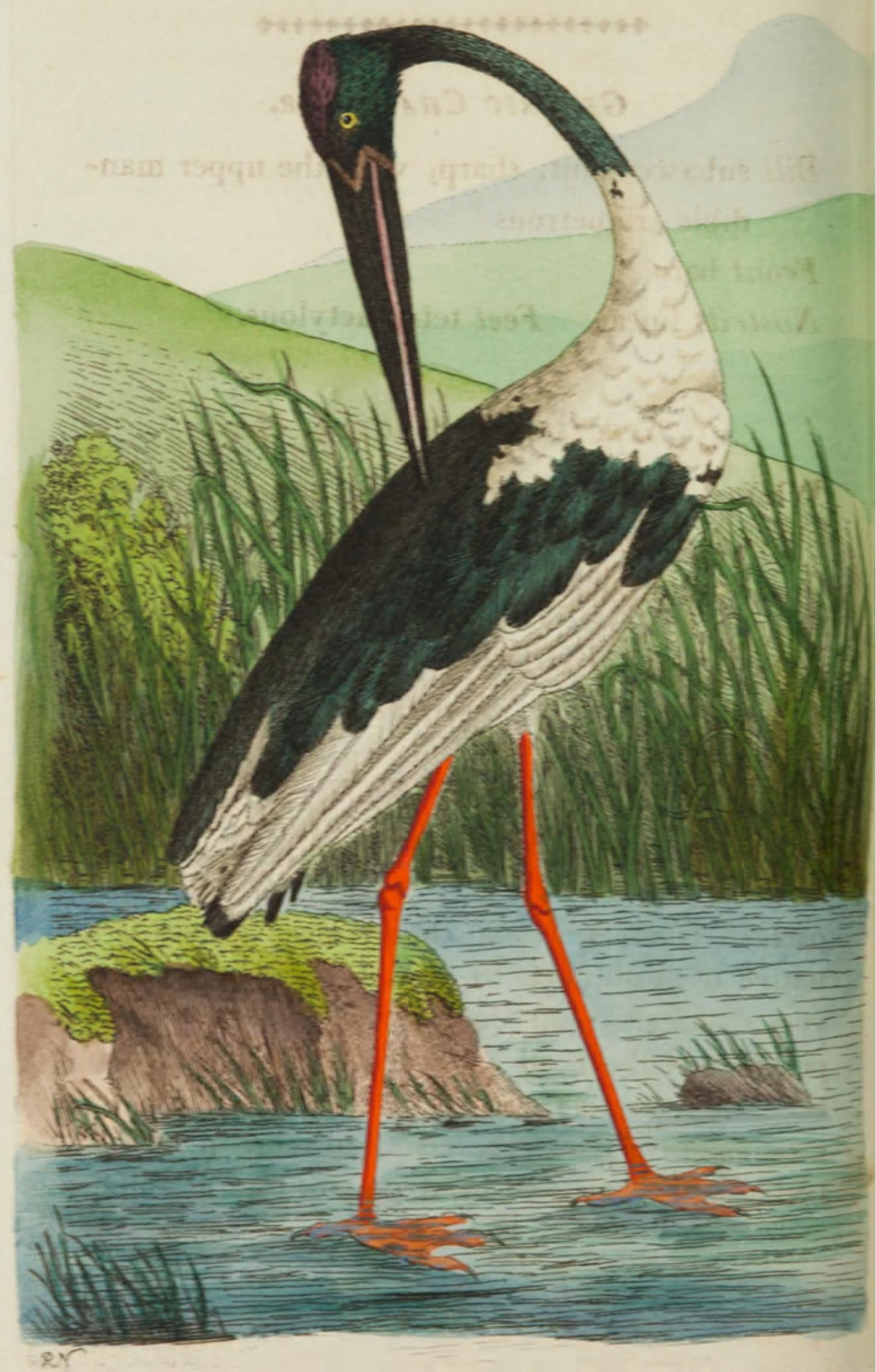


THE

\section{AUSTRALASIAN JABİUU.}

\section{$4+4 * 4 * 4 * 4 * * * * 4+4 * * 4 * 4 * 4$}

\section{GENERIC CHARACTER.}

Bill subascendant, sharp; with the upper mandible triquetrous.

Front bare.

Nostrils linear. Feet tetradactylous.

\section{SPECIFIC CHARACTER, छृC.}

White JABIRU, with the head and neck greenblack; the coverts, scapulars, and tail black; the bill black, and the legs red.

New Holland JABIRU.

Lin. Trans. Vol. 5. p. 34.

The common or American Jabiru has long since been known to naturalists, and is found in many parts of South America. The present species is a native of Australasia, or New Holland, and differs very strikingly from the American bird in the appearance of the head and neck, which, instead of being bare, are entirely covered with feathers of a most elegant dark green, similar to those of a mallard, and accompanied by an elegant blue or purple

D 2 changeable 
changeable lustre. The bill is black, and beneath the lower mandible, to some little distance down the throat, is an extensile naked skin or sacculus of a bright red colour : the rest of the bird is of a snowy whiteness, the coverts of the wings, and the tail excepted, which are jet-black : the legs and feet are of a bright red. According to some very accurate drawings, in the collection of Mr. White, Chief Surgeon to the Settlement at Botany Bay, this species, when full-grown, must be equal in size to the common Jabiru, being not less than six or seven feet high. The present specimen, however, which is preserved in the Leverian Museum, falls short of the height just mentioned, scarcely exceeding that of four and a half, or five feet. 


\section{$2 \mathrm{BHL}$ Biodiversity Heritage Library}

Shaw, George. 1803. "The Australian Jabiru, Mycteria australis [PI. 601]." The Naturalist's Miscellany 15(CLXXII), https://doi.org/10.5962/p.311044.

View This Item Online: https://www.biodiversitylibrary.org/item/280634

DOI: https://doi.org/10.5962/p.311044

Permalink: https://www.biodiversitylibrary.org/partpdf/311044

\section{Holding Institution}

Museums Victoria

\section{Sponsored by}

Atlas of Living Australia

\section{Copyright \& Reuse}

Copyright Status: Public domain. The BHL considers that this work is no longer under copyright protection.

This document was created from content at the Biodiversity Heritage Library, the world's largest open access digital library for biodiversity literature and archives. Visit BHL at https://www.biodiversitylibrary.org. 